\title{
Editorials
}

\section{Anesthesia, ethics, and severe acute respiratory syndrome}

\author{
Joan C. Bevan MD MHSc FRCA, ${ }^{*}$ Ross E.G. Upshur MD BA(hons) MA MSc FrCPC $†$
}

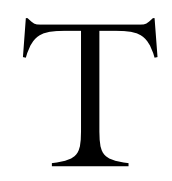

HE fear engendered by the high incidence of infection in health care workers during the recent outbreak of severe acute respiratory syndrome (SARS) in Canada made many anesthesiologists reluctant to treat affected patients. Anesthesiologists, respiratory technologists, intensive care staff and emergency room personnel have been exposed to the greatest possible occupational hazard when performing tracheal intubation on SARS infected patients. Initially, the potential risks that confronted anesthesiologists were not known. Scientific information soon linked SARS to a coronavirus which can remain viable in secretions, vomit and feces, even on dry surfaces, for up to four days. Transmission between humans is droplet spread, making face to face contact between anesthesiologists and patients extremely hazardous. New clinical practice guidelines and protocols for tracheal intubation were developed for managing SARS cases to prevent nosocomial infection. ${ }^{1,2}$ Despite the introduction of these measures, it is not surprising that one anesthesiologist, preparing to perform tracheal intubation on a SARS patient, recalled thinking "Why me?"

Although the World Health Organization removed Toronto as a SARS affected area on July 2, 2003, communicable diseases are ubiquitous in medical practice, and new infectious agents will emerge as challenges in the future. They strike as much fear into people now as they did in Daniel Defoe's 1772 description of the 1665 Great Plague of London. His descriptions of the effects on daily life resonate today: "Great were the confusions at that time upon this very account, and when people began to be convinced that the infection was received in this surprising manner from persons apparently well, they began to be exceeding shy and jealous of everyone that came near them" and "So the plague defied all medicines; the very physicians were seized with it....men went about prescribing to others and telling them what to do....and they dropped down dead, destroyed by that very enemy they directed others to oppose. This was the case of several of the most skilful surgeons." The disruption that the SARS outbreak produced in the 21 st century healthcare system was described, more succinctly, by one anesthesiologist "It brought my hospital to its knees".

There is no doubt that such epidemics impose burdens on us all, producing individual and social human reactions which were brilliantly captured by Albert Camus in 'The Plague'. His young surgeon, Dr Rieux, expresses as much frustration in his battles with bureaucracy as against the plague. When he wants to put victims of unidentified fevers into isolation, he is met with resistance from colleagues, who do not believe that the disease is infectious. Plague brought all social classes to the same level, binding people together, yet keeping them apart. All were equally troubled but did not know how to help each other. As the plague subsided, Camus saw it as no longer a shadowy menace, but a fact that has firmly rooted itself....with a diversity and an adaptability belonging to the philosophy of adapting and surviving....seemingly human and therefore combatable. He concluded that "It is not rebellion itself which is noble but the demands it makes upon us." Camus was awarded the Nobel prize in 1957 for having 'Illuminated the problems of the human conscience in our times'.

\footnotetext{
From the Department of Anesthesia, ${ }^{*}$ Women's College Campus, Sunnybrook \& Women's College Health Sciences Centre; and the Departments of Family \& Community Medicine \& Public Health Sciences and Primary Care Research Unit, $†$ Sunnybrook \& Women's College Health Sciences Centre and Joint Centre for Bioethics, University of Toronto, Toronto, Ontario, Canada.

Address correspondence to: Dr. Joan C. Bevan, Department of Anesthesia, Room 203, Women's College Campus, Sunnybrook and Women's Health Sciences Centre, 76 Grenville Street, Toronton, Ontario M5S 1B2, Canada. Phone: 416-323-6008; Fax: 416-323-6307; E-mail: joan.bevan@utoronto.ca

Funding sources: none.

Conflicts of interest: none.
} 
In comparison to HIV/AIDs, which killed 25 million people, predominantly in the developing world, the impact of 800 SARS deaths has been borne by a small proportion of the world's population, largely in developed countries. In Canada, at the time of writing, there have been 250 cases of SARS, almost entirely confined to the Toronto area, with 40 deaths and 17 patients not yet recovered. This is an infection which targets the respiratory system, like influenza, the cause of a major epidemic in the early 1900s, when medical technology was not advanced. SARS produces an atypical pneumonia, and at least $20 \%$ of cases can benefit from the availability of respiratory ventilation in intensive care units. Thus, the SARS crisis has introduced hitherto unanticipated ethical and medical challenges for anesthesiologists.

Reflecting on the management of the SARS crisis, a working group at Toronto's Joint Centre for Bioethics identified a number of ethical issues where important lessons were learned. These related to public health ethics (quarantine and information sharing), clinical ethics (duty to care and collateral damage) and global health ethics. They articulated a values based decision making framework for analysis which would be applicable in future outbreaks, rather than a set of rigid rules to apply when conditions may be different. Reliance would be placed on meeting key societal values, such as the right to privacy, the need to protect the public from harm, individual liberty and the need to protect communities from stigmatization and to respond in proportion to the problem. The issue on which consensus could not be reached was how far the duty of care extended, or, what obligations healthcare workers have to provide care when their own health could be put in jeopardy.

In the absence of specific treatment or vaccination against SARS, anesthesiologists were confronted with an increased risk of contracting the disease. Some clumsy attempts at intubation of patients with a relatively poor chance of eventual survival, led to spread of the disease and gave rise to consideration of whether the procedure was futile. As the experts with the technical skill to perform tracheal intubation rapidly under sedation and muscle paralysis, anesthesiologists offered their expertise to assist critical care physicians. For a number of anesthesiologists, their moral values dictated that they should treat the SARS patient without regard to the consequences for their own safety. However, the implications of so doing had to be a strong disincentive. Many experienced fears of infection, the likelihood of passing this on to their families, and the economic consequences of becoming sick. Working conditions were stressful due to the awkwardness of having to wear protective masks, goggles, hoods and gowns, the need to follow new protocols to prevent cross contamination, and an increased workload if colleagues were sick or in quarantine. These circumstances made anesthesiologists vulnerable to extreme moral distress.

What risks should health care workers be willing to countenance? Are they obliged by a duty of care to put themselves and their families at risk? Anesthesiologists have conflicting legal and ethical responsibilities. They are enjoined by the first principle of the Canadian Medical Association's Code of Ethics to "Consider first the well being of the patient" while recognizing their duty to protect themselves and others. The prima facie, fiduciary duty of care which physicians owe to their patients is a relationship of mutual trust, confidence and good faith. Physicians are expected to use their expertise for the benefit of the patient in return for the privileges of belonging to a highly regarded profession. Failure to meet this standard is a breach of duty of care amounting to professional negligence. If injury results, a claim for damages for wrongful death or injury would be successful. On the other hand, hospitals have a duty to provide a safe working environment for professionals. If patients present risks of infection to caregivers, they in turn have duties to protect themselves and avoid spread of the infection to others: patients, colleagues and their own families. During the SARS outbreak, some anesthesiologists questioned whether they must treat suspected cases, or considered breaking quarantine restrictions because of loss of income.

Communicable diseases underscore human vulnerability and a fearful response to contagion is understandable, particularly in a context where the infectious agent is poorly understood and the science is evolving. Health care workers are as capable of infecting patients as they are likely to be infected by them. It was not long ago that health care workers expressed concern for treating patients with HIV infection. The use of universal precautions has allayed most of these fears and normalized approaches to HIV patients. Rigorous adherence to infection control measures can reduce, but not eliminate the risk of transmission. However, it is essential that anesthesiologists reflect on how the line is drawn between selfprotection and dereliction of duty to determine the appropriate scope of care which should become the accepted 'standard of care' to meet our 'duty of care'.

More information is needed to understand why SARS spread so easily among health care workers. Was this despite taking adequate precautions or because the precautions that were taken were incomplete? The 
potential and real risks must be assessed in treating infected cases. If it is true that the appropriate precautions can prevent spread, these must be identified and put in place. In the early stages of the SARS epidemic there were many uncertainties. Experience has shown that respiratory failure occurs over a matter of days, not minutes. When the patient's condition begins to deteriorate, tracheal intubation can be performed as a planned procedure.

If the new protocols for tracheal intubation are proven to be effective in preventing the spread of infection, and the anesthesiologist is hypervigilant in their application, any fear will decrease. In a patient with a highly infectious disease, such as SARS, when there is ample time to apply protocols, they work well. However, it takes $15 \mathrm{~min}$ to don protective clothing and that would be an unacceptable response time in an acute cardiac arrest situation. Early in the SARS outbreak, some health care workers were infected when tracheal intubation was attempted in undiagnosed cases, without using any protective measures. The difficulty arises in resuscitation of people who have an unexplained, sudden cardiac arrest, which could be associated with a contagious disease. If all patients are going to be seen as a threat to the caregivers in the future, will all have to be treated equally? Obviously not, as delays could be fatal. To meet these situations, a new 'Protected Code Blue' protocol has been recommended to enable rapid tracheal intubation of patients with highly infectious diseases, using modified protective wear to safeguard the operator as well as possible. ${ }^{1,2}$ There are residual concerns that spread of SARS infection may have occurred in fully protected health care workers and research is needed to evaluate these new protocols and their efficacy. Empirical research work is needed to predict the dynamics of transmission in healthcare settings and the epidemiological spread in communities, from the perspectives of health care workers and patients.

The SARS experience has shown that, in emerging situations, the ethical issues for anesthesiologists should be recognized and professional codes and ethical obligations redefined. We have discussed the need to re-evaluate the doctor-patient relationship when it is the source of moral distress that affects care. Emphasis is placed on responding in a professionally appropriate manner to meet our duty of care in changing and challenging circumstances. By accepting new peer reviewed practice guidelines as modifications to traditional standards of care, new standards of care are created. This resolution of the ethical dilemmas for anesthesiologists involved in the care of SARS patients, should act as a model to ensure that the arrival of another infectious plague in Toronto will be less dreaded.

\section{Anesthésie, éthique et syndrome respiratoire aigu sévère}

La peur engendrée par l'importante incidence d'infection chez le personnel de la santé pendant la récente éclosion du syndrome respiratoire aigu sévère (SRAS) au Canada a rendu de nombreux anesthésiologistes réticents à traiter les patients infectés. Les anesthésiologistes, les inhalothérapeutes, le personnel des soins intensifs et de l'urgence ont été exposés au plus grand risque professionnel possible. Initialement, les risques potentiels auxquels les anesthésiologistes étaient confrontés n'étaient pas connus. Les informations scientifiques ont bientôt relié le SRAS à un coronavirus qui peut demeurer viable jusqu'à quatre jours dans les sécrétions, les vomissures et les fèces, même sur des surfaces sèches. La transmission entre humains par des gouttelettes de salive a rendu le contact face à face extrêmement risqué entre les anesthésiologistes et les patients. De nouvelles directives de pratique clinique et de protocoles d'intubation endotrachéale ont été élaborées pour traiter les cas de SRAS et prévenir l'infection nosocomiale. ${ }^{1,2}$ Malgré ces mesures, il n'est pas surprenant qu'un anesthésiologiste se préparant à réaliser une intubation endotrachéale chez un patient atteint du SRAS se dise «Pourquoi moi ?»

Même si, le 2 juillet 2003, l'Organisation mondiale de la santé a retiré Toronto de la liste des endroits affectés par le SRAS, les maladies transmissibles sont fréquentes en pratique médicale et de nouveaux agents infectieux vont se présenter comme de futurs défis à affronter. Ils saisissent d'effroi autant maintenant que dans la description que Daniel Defoe a faite en 1772 de la peste de Londres survenue en 1665. Sa description des effets sur la vie quotidienne résonne encore aujourd'hui : "Grandes furent les confusions à cette époque en raison de cette maladie et lorsque les gens ont commencé à se rendre compte que l'infection venait de manière étonnante de personnes apparemment en bonne santé, ils sont devenus excessivement méfiants et hostiles envers quiconque s'approchait d'eux» et "Ainsi, la peste défia tous les médicaments ; les médecins eux-mêmes en étaient atteints... les hommes allaient, s'imposant aux autres et leur disant quoi faire... et ils tombaient raides morts, détruits par l'ennemi même auquel ils ordonnaient aux autres de s'opposer. Ce fut le cas de quelques chirurgiens des 
mieux qualifiés.» Le désordre que l'éclosion du SRAS a provoqué dans le système de santé du $2 \mathrm{I}^{\mathrm{c}}$ siècle a été décrit, plus succinctement, par un anesthésiologiste : «Cela a mis mon hôpital à genoux».

Il ne fait aucun doute que cette épidémie impose des fardeaux à tous, produisant des réactions individuelles et sociales brillamment décrites par Albert Camus dans La peste. Son jeune chirurgien, le Dr Rieux, exprime autant de frustration dans sa lutte avec la bureaucratie que dans celle qu'il mène contre la peste. Quand il veut isoler des victimes de fièvres non identifiées, il rencontre la résistance de ses confrères qui ne croient pas que la maladie soit infectieuse. La peste ramène toutes les classes sociales au même niveau, liant les gens tout en les divisant. Tous étaient également troublés mais ne savaient comment s'aider les uns les autres. À mesure que la peste se répandait, Camus a constaté qu'elle ne représentait plus une menace obscure, mais un fait qui s'était fermement enraciné lui-même... selon une diversité et une adaptabilité appartenant à la philosophie de l'adaptation et de la survie... presque humaine et que l'on peut donc combattre. Il concluait que «Ce n'est pas la rébellion qui est noble, ce sont les efforts qu'elle exige de notre part.» Camus a gagné le prix Nobel en 1957 pour avoir «éclairé les problèmes actuels de la conscience humaine.»

En comparaison du VIH/SIDA, qui a tué 25 millions de personnes, surtout dans le monde en développement, l'impact des 800 décès par le SRAS a été subi par une petite proportion de la population mondiale, surtout dans les pays développés. Au Canada, présentement, il y a eu 250 cas de SRAS, presque tous dans la région de Toronto, dont 40 décès et 17 patients non encore rétablis. C'est une infection qui cible le système respiratoire, comme l'influenza qui a causé une épidémie majeure au début des années 1900 alors que la technologie médicale n'était pas aussi avancée. Le SRAS produit une pneumonie atypique et $20 \%$ des cas au moins ont bénéficié de la disponibilité de la ventilation respiratoire à l'unité des soins intensifs. Ainsi, la crise du SRAS a présenté jusqu'ici des défis éthiques et médicaux inattendus pour les anesthésiologistes.

Lors d'une réflexion sur la gestion de la crise du SRAS, le groupe de travail du Toronto's Joint Centre for Bioethics a déterminé un certain nombre de questions éthiques où d'importantes leçons avaient été apprises. Celles qui concernent l'éthique de la santé publique (quarantaine et partage de l'information), l'éthique clinique (devoir de diligence et dommages collatéraux) et l'éthique de la santé globale. Ils ont formulé un cadre de travail concernant la prise de décision fondée sur les valeurs pour l'analyse, qui serait applicable à de futures éclosions, plutôt qu'un ensemble de règles rigides à appliquer lorsque les conditions seraient différentes. La cohésion devra reposer sur le fait de répondre aux valeurs sociétales clés, comme le droit à la vie privée, le besoin de protéger le public, la liberté individuelle et le besoin de protéger les communautés de la stigmatisation et de répondre en proportion du problème. La question qui n'a pu recueillir de consensus portait sur l'extension du devoir de diligence, ou quelles obligations les travailleurs de la santé doivent-ils remplir lorsque leur propre santé peut être en danger.

En l'absence de traitement spécifique ou de vaccin contre le SRAS, les anesthésiologistes ont été confrontés à un risque accru de contracter la maladie. Des tentatives maladroites d'intubation de certains patients qui présentaient peu de chances de survie ont favorisé la propagation de l'infection et amené à considérer la futilité de la manœuvre. En qualité d'experts possédant les habiletés techniques pour réaliser une intubation endotrachéale rapide sous sédation et paralysie musculaire, les anesthésiologistes ont offert leur expérience pour assister les intensivistes. Pour un certain nombre d'anesthésiologistes, il fallait, en accord avec leurs valeurs morales, traiter le patient atteint de SRAS sans égard aux conséquences pour leur propre sécurité. Cependant, les implications de ce geste auraient dû constituer un élément fort dissuasif. Beaucoup ont craint l'infection, la possibilité de contaminer leur famille et les conséquences économiques d'être malades. Les conditions de travail étaient stressantes à cause de l'inconvénient de devoir porter masques, lunettes, cagoules et blouses pour se protéger, de la nécessité de suivre de nouveaux protocoles pour prévenir la contamination croisée et de la charge de travail accrue si des collègues tombaient malades ou se retrouvaient en quarantaine. Ces circonstances ont rendu les anesthésiologistes très vulnérables à un stress moral extrême.

Quels risques les travailleurs de la santé devraientils accepter de prendre ? Sont-ils tenus par une obligation de diligence de mettre en danger eux-mêmes et leurs familles? Les anesthésiologistes ont des responsabilités légales et éthiques conflictuelles. Ils sont obligés par le premier principe du Code d'éthique de l'Association médicale canadienne de "Considérer d'abord le bien-être du patient» tout en reconnaissant leur devoir de protéger eux-mêmes et les autres. À première vue, l'obligation de diligence de nature fiduciaire que les médecins doivent à leurs patients est une relation de confiance mutuelle, de confidentialité et de bonne foi. Les médecins doivent mettre leur expérience au service du patient en retour du privilège d'ap- 
partenir à une profession tenue en haute estime. Le défaut de répondre à cette norme constitue une infraction au devoir de diligence équivalente à une négligence professionnelle. Si des lésions en résultent, une demande d'indemnisation pour un délit ayant causé la mort ou des blessures serait favorablement reçue. D'autre part, les hôpitaux sont tenus de procurer aux professionnels un environnement de travail sécuritaire. Si les patients représentent un risque d'infection pour les soignants, ces derniers ont, en retour, l'obligation de se protéger eux-mêmes et d'éviter de propager l'infection aux autres : patients, collègues et familles. Pendant la crise du SRAS, certains anesthésiologistes se sont demandé s'ils devaient traiter des cas suspects ou s'ils pouvaient se soustraire aux restrictions de la quarantaine pour perte de revenus.

Les maladies transmissibles soulignent la vulnérabilité humaine, et la réaction de peur à la contagion est compréhensible surtout dans un contexte où les agents infectieux sont peu connus et où la science se développe. Les travailleurs de la santé peuvent infecter des patients autant qu'être infectés par eux. Il n'est pas loin le temps où le personnel de la santé exprimait ses craintes de traiter des patients porteurs du HIV. L'utilisation de précautions universelles a permis de vaincre la peur et a normalisé la façon de traiter ces patients. L'adhésion rigoureuse aux mesures de contrôle de l'infection peut réduire, mais non éliminer, le risque de transmission. Il est cependant essentiel que les anesthésiologistes réfléchissent sur la manière de tracer la ligne entre l'autoprotection et le manquement à ses devoirs afin de déterminer le cadre de soins appropriés qui pourrait devenir une «norme de conduite» acceptée répondant à notre «devoir de diligence».

On ne sait encore pourquoi le SRAS s'est propagé si facilement parmi le personnel de la santé. Est-ce à cause de précautions inadéquates ou incomplètes ? Les risques potentiels et réels doivent être évalués quand on traite des malades infectés. Si des précautions appropriées permettent de prévenir la propagation, elles doivent être définies et mises en place. Au début de l'épidémie de SRAS, il y avait beaucoup d'incertitudes. L'expérience a montré que l'insuffisance respiratoire survient en quelques jours, non en quelques minutes. Quand l'état du malade commence à se détériorer, l'intubation endotrachéale peut être réalisée comme une mesure planifiée.

Si les nouveaux protocoles d'intubation endotrachéale se montrent efficaces à prévenir la propagation de l'infection, et si les anesthésiologistes sont très vigilants à les appliquer, toute crainte va se dissiper. Les médecins interviennent efficacement auprès d'un patient atteint d'une maladie très infectieuse, comme le SRAS, quand il y a amplement de temps pour appliquer les protocoles. Cependant, il faut 15 min pour enfiler les vêtements de protection, ce qui serait un retard inacceptable dans une situation d'arrêt cardiaque aigu. Au début de l'éclosion de SRAS, des travailleurs de la santé ont été infectés en procédant à l'intubation endotrachéale chez des cas non diagnostiqués sans utiliser les mesures de protection. Le problème survient pendant la réanimation de patients qui sont victimes d'un arrêt cardiaque soudain et inexpliqué pouvant être associé à une maladie contagieuse. $\mathrm{Si}$, dorénavant, tous les patients deviennent une menace pour les travailleurs de la santé, devront-ils être tous traités de la même manière ? Certainement pas, puisque tout retard pourrait être fatal. Pour faire face à ce genre de situations, un nouveau protocole de «Code bleu de protection» a été recommandé pour faciliter l'intubation trachéale rapide des patients atteints de maladies très infectieuses. Il utilise des articles de protection modifiés pour protéger l'opérateur autant que possible. ${ }^{1,2}$ On se demande encore si la propagation du SRAS peut se produire chez des travailleurs de la santé complètement protégés. D'autres recherches sont donc nécessaires, de même que l'évaluation de ces nouveaux protocoles et de leur efficacité. Un travail de recherche empirique est requis pour prédire la dynamique de la transmission dans le cadre clinique et la propagation épidémiologique dans la communauté, selon les perspectives des travailleurs de la santé et des patients.

L'expérience du SRAS a montré que, pour les anesthésiologistes impliqués dans des situations nouvelles, les questions d'éthique doivent être reconnues et les codes professionnels et les obligations éthiques redéfinis. Nous avons discuté de la nécessité de réévaluer la relation médecin-patient quand elle est une source de détresse morale affectant les soins. L'accent est mis sur le fait de répondre d'une manière professionnelle appropriée afin de satisfaire à notre devoir de prudence dans des circonstances qui changent et posent de nouveaux défis. En acceptant de nouvelles directives de pratique révisées par les pairs, qui modifient les normes traditionnelles, on crée de nouvelles normes de soins. Cette résolution des dilemmes éthiques pour les anesthésiologistes impliqués dans le traitement de patients atteints du SRAS devrait servir de modèle pour s'assurer que l'éclosion d'une nouvelle peste infectieuse à Toronto sera moins redoutée.

\section{References}

1 Canadian Anesthesiologists' Society. Proposed guidelines prepared by anesthesiologists at six University of Toronto affiliated hospitals. May 2, 2003. Anesthetic 
management of a SARS-infected patient and Policy for emergency tracheal intubation of SARS patients outside the OR. Available for URL; http://www.cas.ca/ (Site restricted to members: accessed July 15, 2003).

2 Peng PWH, Wong DT, Bevan D, Gardam M. Infection control and anesthesia: lessons learned from the Toronto SARS outbreak. Can J Anesth 2003; 50: 989-97. 